\title{
MAKNA TEOLOGI \\ DALAM NOVEL TUHAN MAHA ASYIK SUDJIWO TEDJO DAN DR. MN. KAMBA
}

\author{
Oleh: \\ Rahmat Firdaus \\ Jurusan Aqidah dan Filsafat Islam Fakultas Ushuluddin \\ Universitas Islam Negeri Sunan Gunung Djati Bandung \\ e-mail: rahmatfirdaus03@gmail.com
}

\begin{abstract}
Abstrak
Tuhan, dengan pelbagai misterinya telah memberikan anasir pada manusia bahwa pencarian akan Dia akan pencarian yang-selain merupakan kegiatan terus-menerus dan tiada henti-juga memberikan keasyikan. Itu sebabnya Tuhan Maha Asyik: entah sebagai bahan telaah, maupun sebagai tujuan dari seluruh poros aktivitas manusia. Pemahaman akan Tuhan menurut pengarang itu sangat menarik untuk di ketahui, karena buku Tuhan Maha Asyik ini sangat berbeda dengan buku Teologi yang lain. Metode berpikir yang digunakan adalah Hermeneutik. Hasil penelitian atas novel Tuhan Maha Asik karangan Sudjiwo Tedjo dan DR. MN. Kamba, menunjukkan sebuah arah pada cerita-cerita yang unik, mulai dari pembahasan wayang, marhain, cacing, diri dan lain sebgainya, yang dibawakan dengan analogi-analogi ala anakanak. Adapun makna teologi yang terkandung dalam buku ini adalah teologi kesejatian diri. Dimana kita dapat mengenal Tuhan melalui tiap-tiap diri manusia, namun diri yang dimaksud disini adalah diri yang fitrah bukan diri yang telah di masuki oleh konsep-konsep yang terbentuk dari masyrakat atau dari luar diri.
\end{abstract}

Kata Kunci : Makna, Teologi, Tuhan

\begin{abstract}
God, with its various mysteries, has given man the element that the search for Him for a search which - apart from being a continuous and unending activity - also gives pleasure. That is why God is most fun: either as an object of study, or as the goal of the entire axis of human activity. The author's understanding of God is very interesting to know, because this book of God is Most Fun is very different from other Theology books. The thinking method used is hermeneutics. The results of research on the novel Tuhan Maha Asik written by Sudjiwo Tedjo and DR. M N. Kamba, shows a direction in unique stories, starting from the discussion of wayang, marhain, worms, self and so on, which is presented with analogies in the style of
\end{abstract}


children. The theological meaning contained in this book is theology of authentic self. Where we can know God through each human being, the self that is meant here is a natural self, not a self that has been entered by concepts formed from society or from outside.

Keywords: Meaning, Theology, God

\section{A. Pendahuluan}

Setiap manusia yang dilahirkan kedunia dalam keadaan suci dan beragma, dalam menentukan agamanya biasanya ditentukan oleh dimana dia dilahirkan, dalam lingkungan apa dan oleh orang tua yang beragama apa dia dilahirkan. Kebanyakan manusia hanya pasrah saat menerima bahwa dirinya harus beragama sesuai dengan keadaan lingkungan dan keluarga. Seseorang yang beragama, berarti mereka yang meyakini bahwa dirinya ber Tuhan, meyakini kehidupan setelah mati, dan meyakini adanya surga dan neraka. Dalam keyakinan mereka harus percaya sepenuh hati dan menjalankan perintah-perintah yang terdapat pada ajaran agamanya, guna untuk menjadikan dirinya makhluk yang taat dan disayangi oleh Tuhan nya.

Agama diyakini oleh penganutnya sebagi sebuah ajaran yang berisi tentang kebenaran tertinggi yang mutlak, serta petunjuk-petunjuk dalam menjalankan kehidupan di dunia dan akhirat dengan selamat. Agama hadir untuk menjadikan manusia lebih baik dan dapat membantu manusia untuk mengenal Tuhannya. Sebagaimana yang dikutip oleh Hussein Bahreis, dalam proses mengenal Tuhan menurut Al Ghazali harus sedekat dekatnya, mengawali dengan pensucian jiwa dan zikir kepada Nya secara terus menerus, sehingga pada akhirnya akan mampu melihat Tuhan dengan hati nurani ${ }^{1}$. Itulah salah satu konsep ma'rifatulla dalam islam untuk mengenal Tuhan nya.

Sujiwo Tejo dan DR. MN. Kamba dalam bukunya yang berjudul "Tuhan Maha Asyik" mencoba mengajak kita sebagai umat manusia untuk mengenal lebih dekat dengan Tuhan melalui cara yang berbeda. Jika Tuhan sering kita tau sebagai sesuatu yang sacral dan tabu untuk dipertanyakan sebagai peroses mengenalNya, namun dalam buku Tuhan Maha Asyik ini menyuguhkan pengenalan Tuhan lewat analogi-analogi yang diceritakan oleh kehidupan sehari-hari anak-anak dan kontekstual dengan kebudayaan masyarakat Indonesia, sehingga mudah dipahami. Buku ini akan membawa kita kepada sebuah pemikiran yang akan menampung ide tentang ketuhanan dan keberagamaan yang lebih luas dan lebih asyik.

\footnotetext{
${ }^{1}$ Hussein Bahreis, Ajaran-ajaran Akhlak Al-Ghazali, (Surabaya: Al-Ikhlas, 1981), 104.
} 
Dalam dunia ke ilmuan untuk mengenal Tuhan, dapat dipahami melalu teologi. Teologi yang berarti ilmu yang membahas tentang ketuhanan, mulai dari zat Tuhan, perkataan Tuhan, bahkan perbuatan Tuhan dalam segala aspek yang menggunakan argument rasional. Teologi berasal dari kata theos yang berarti Tuhan dan logos yang berarti ilmu, dengan demikian teologi membicarakan tentang Tuhan, wacana subtansi pada teologi selalu berpusat pada tuhan dan konteks teologi yaitu konteks tentang ketuhanan. Dengan begitu Tuhan adalah "penanda" utama dalam teologi, seluruh fondasi teologi dibangun diatas aspek kehadiran Tuhan sebagai faktor pertma. Dalam aspek metodologis, teologi menurut Muhammad Al- Fayyadl dapat dibagi kedalam dua hal, yang pertama sebagai "sistem keyakinan dan yang kedua sebagi "kajian"

Sebagai sistem keyakinan, teologi merupakan seperangkat dokrin yang diyakini oleh kaum bergama dan dijalankan dengan sepenuh hati. Ajaran ajaran yang melekat pada agama diyakini akan menuntut umat manusia kepada ke bahagian. Sedangkan teologi sebagai kajian, adalah sebuah konsep-konsep ketuhanan yang dikembangkan melalui studi, atau penelitian dan pendekatan seputar Tuhan dan agama. Teologi sebagai kajian lebih bersifat kritis dari pada normative, karena dalam hal ini teologi berisi tentang wacana-wacana teoritis, dan diskursus filososi tentang ketuhanan.

Buku "Tuhan Maha Asyik" menyimpan banyak makna teologi, pembaca akan diajak untuk mengenal bagaimana kedudukan Tuhan dan manusia, mengal zat Tuhan dan sebagainya. Melalui kisah kisah yang dikemas dalam dialog-dialog polos ala dunia anak-anak, Sujiwo Tejo dan Buya MN. Kamba mencoba mengajak para pembacanya untuk bermain-main untuk memperkenalkan ke Maha Asyikan Tuhan. Tuhan sangat asyik ketika Dia tidak kita kurung paksa dalam penamaan-penamaan dan pemaknaanpemaknaan, Dia tak terdefinisikan dan Dia tak termaknakan. Dia ada sebelum definisi dan makna ada. Tuhan itu anti mainstream. Tuhan itu Maha Asyik ketika kita mencoba untuk mentadabhuri-Nya, bukan melogikan -Nya ${ }^{3}$. Ini lah yang coba Sujiwo Tejo dan DR. MN. Kamba sajikan untuk mengenal Tuhan. Melalui pengalaman akademisi ke ilmuan filsafat dan sufistik, DR.MN. Kamba menjelaskan fenomena kebertuhanan yang ada di Indonesia dan dikemas sebegitu menarik dengan analogi-analogi yang dipaparkan oleh Sujiwo Tejo melalui pengalamanya dalam bidang seni dan sastra.

\footnotetext{
${ }^{2}$ Muhammad Al-Fayyadl, Teologi Negatif Ibn Arabi: Kritik Metafisika Ketuhanan, (Yogyakarta: LKiS, 2012), 63-64.

${ }^{3}$ Sujiwo Tejo dan DR.MN. Kamba, Tuhan Maha Asyik, (Tanggerang: Imania, 2017).
} 
Dalam buku Tuhan Maha Asyik kedua penulis ini mencoba memperlihatkan bagaimana tindakan manusia yang menyekutukan Tuhan itu karena menyembah yang selain Nya, selain itu menjak kita untuk selalu bersabar dan berikhtiar ketika diberi cobaan. Buku ini juga mengkritik bagaimana prilaku manusia yang sering mengklaim Tuhan adalah seperti apa yang kita pikirkan, sehingga membatasi Tuhan yang notabenya Maha tidak Terbatas. Ketika makna Tuhan di sekat dalam konsep-konsep pemikiran manusia, maka Tuhan akan semakin jauh dari diri manusia, jadi kita dapat menemui Tuhan melalui beragam ciptaan Nya, sehingga disitu kita dapat melihat dan memaknai keasyikan dalam memahami Tuhan.

"Ketika manusia memandang cermin, bukan kaca yang terlihat namun dirinya. Ketika manusia berbuat baik pada orang lain, sejatinya dia berbuat baik untuk diri sendiri. Demikian juga ketika dia menyakiti sesama, justru menyakiti diri sendiri. Jadi wajar saja ketika orang menyakiti diri sendiri dianggap gila. Namun, lebih gila lagi jika agama dan atas nama Tuhan menjadi alasan untuk membenci dan menyakiti”" Ini adalah sepenggal kutipan yang terdapat pada buku Tuhan Maha Asyik, yang dapat disimpulkan bahwa kita belajar pada diri kita sendiri, seperti dikatakan oleh sokrates "kenalidirimu, maka kamu akan mengenali Tuhanmu".

Dalam buku Tuhan Maha Asyik ini berisi penjelasan tentang keberagamaan untuk mengenal Tuhan, maka dengan itu peneliti menggunkan pendekan hermeneutic dalam memahami teks. Hermeneutic berasal dari kata Yunani yaitu hermeneuein yang berarti menafsirkan, sedangkan kata bendanya yaitu hermenia, yang dikaitkan dengan salah satu nama dewa yaitu Hermes. Dewa Hermes dalam mitologi Yunani, ia bertugas sebagai juru hubung atau penghubung anatara Sang Maha Dewa dengan manusia. Tugas ini mirip dengan para $\mathrm{Nabi}^{5}$ dan Rasul dalam menafsirkan kitab suci agar dapat dipahami oleh umat manusia, sehingga tidak ada kesalah pahaman dalam memaknai kitab suci tersebut.

Menurut Zygmunt Bauman, seperti yang dikutip oleh Kurt F. Leidecker, hermeneutic dapat dipahami sebagai upaya untuk menjelaskan sebuah pesan dan teks-teks dalam sebuah ucapan ataupun tulisan yang tidak jelas, kabur, remang-remang dan kontradiktif, yang menyebabkan kebingungan bagi pembacanya atau pendengarnya. Secara umum, hermeneutic dipahami sebagai sebuah seni dalam ilmu untuk menafsirkan

\footnotetext{
${ }^{4}$ Sujiwo Tejo dan DR.MN. Kamba, Tuhan Maha Asyik, (Tanggerang: Imania, 2017), 113.

5 Komaruddin Hidayat, Memahami Bahasa Agama Sebuah Kajian Hermeneutik (Jakarta: Paramadina, 1996), 13.
} 
teks-teks yang mempunyai otoritas, khususnya teks suci ${ }^{6}$. Awalnya hermeneutic di artikan sebagai pola yang digunakan oleh seorang penafsir dalam memahami teks keagamaan, namun seiring berjalanya waktu, hermeneutic tidak hanya digunakan untuk memahami teks suci saja melainkan untuk semua bentuk teks, seperti sastra, karya seni ataupun tradisi masyarakat.

Hermeneutic sebagai metodologi penafsiran, mempunyai 3 bentuk model varian yaitu, hermeneutic objektif yang dikembangkan oleh tokohtokoh klasik seperti Friedrick Schleiermacher, Wilhelm Dilthey, dan Emilo Betti ${ }^{7}$. Dalam bentuk ini Schleiermarcher menjelaskan bahwa penafsiran berarti memahami teks sebagaimana yang dipahami pengarangnya. Selanjutnya hermeneutic subjektif, yang dikembangkan oleh Hans-Georg Gadamer dan Jacques Derrida, hermneutik model ini berbeda dengan hermeneutic objektif yang dikembangkan oleh Schleiermacher, yang memahami teks harus sesuai dengan yang dipahami pengarangnya. Dalam hermeneutic subjektif, teks bersifat terbuka dan dapat diinterprestasikan oleh siapapun tanpa harus sesuai dengan pengarangnya, bahakan dalam pandangan penganut hermeneutic ini penulis telah "mati".

Yang ketiga yaitu hermeneutic pembebasan yang dikembangkan oleh tokoh -tokoh muslim kontemporer khususnya Hasan Hanafi dan Farid Esak.Hermeneutic pembebasan yang dikembangkan oleh Hasan Hanafi ini didasari oleh pemikiran Gadamer mengenai hermeneutic sbujektif. Hermeneutic ini bisa dikatakan sebagai ilmu yang menentekuan hubungan antara kesadaran pada manusisa dengan objeknya dalam hal ini adalah teks suci Al Quran. Keaslian teks itu sangat penting dalam hermeneutic ini, karena pemahaman atas teks yang tidak asli akan menjerumuskan orang pada kesalahan $^{8}$.

Hermeneutic sebagai metode tafsir ini dapat digunakan untuk memahami teks menurut keasliannya, ataupun kesesuaian pemahaman dengan pengarangnya. Oleh karena itu penulis ingin meneliti makna teologi yang terdapat pada buku Tuhan Maha Asyik karya Sujiwo Tejo dan DR.MN. Kamba dengan menggunakan metode analisi hermeneutic.

\footnotetext{
${ }^{6}$ Kurt F. Leidecker,"Hermeneutics" dalam Dagobert Russel (ed), dictionary of philosophy, (New York: Adams dan co, 1976), 126.

${ }^{7}$ Fazlur Rahman, Islam dan Modernitas, terj. Ahsin Muhammad, (Bandung: Pustaka, 1985), 9.

${ }^{8}$ Hasan Hanafi, Dialog Agama dan Revolusi, (Jakarta: Pustaka Firdaus, 1994), 1.
} 


\section{B. Pembahasan Hasil Penelitian}

\section{Sinopsis Novel}

Buku "Tuhan Maha Asyik" karangan Sujiwo Tejo dan Dr. MN. Kamba adalah buku yang membicarakan mengeinai Tuhan. Dalam buku ini menyuguhkan proses mengenal Tuhan melalui analogi-analogi yang diceritakan oleh percakapan anak-anak dalam kehidupan sehari-harinya dan kontekstual dengan kebudayaan masyarakat Indonesia. Bagi sebagian orang, buku ini sangat berat untuk dipahami, namun Sujiwo Tejo dan Dr.MN.Kamba mencoba mengenalkan Tuhan melalui cara yang berbeda yang anti menstream dari buku-buku yang lain yang membahas mengenaiTuhan. Buku Tuhan Maha Asyik menyajikan 28 cerita dengan penamaan judul yang unik-unik. Mulai dari Wayang, Mahraen, Cacing, Zat, Gincu dan masih banyak lainya. Penamaan subjudul yang unik ini memang sengaja agar berbeda dengan buku-buku yang membahas teologi lainnya.

Dalam cerita Wayang, dijelaskan bahwa manusia sebagai wayang dan Tuhan berperan sebagai dalang yang mengatur segalanya dalam cerita pewayangan. Dalang yang memainkan wayang yang menjadikan semuanya terjadi atas kehendak dalang. Secara garis besar wayang yang dimainkan oleh dalang mempunyai peranan dan tugasnya masing-masing dalam menjalankan alur cerita,namun masih dalam kendali dalang dan sang wayang hanya tunduk dan patuh kepada perintah sang dalang, yang mempunyai sekenario, ini dalam wayang kulit. Berbeda lagi dengan wayang orang, dimana sang wayang diberi keleluasaan untuk bergerak sesuka hati dan menjalankan cerita seseuai alurnya. Jika dalam wayang kulit si w ayang hanya mengikuti arahan apa yang di perintahkan sang dalang. Namun dalam wayang orang, si wayang mempunyai kehendak penuh untuk bergerak ataupun berbicara, tetapi masih tetap harus sesuai dengan sekenario sang dalang.

Manusia adalah makhluk yang diberi kelebihan dalam akal sehingga manusia bisa bebas memilih dalam menjalankan kehidupanya. Tuhan selalu meberikan dua pilihan untuk manusia pilih, ada surge ada neraka, ada air ada api, ada siang ada malam, ada kebaikan ada keburukan dan sebagainya. Namun Tuhan sendiri telah memberikan arahan atau petunjuk sebelum kepada para nabi dan rasul untuk manusia, agar manusia dapat menjalankan aktifitasnya sebagai manusia sesuai dengan apa yang telah Tuhan perintahkan, ini tidak jauh beda dengan peran wayang dalam wayang orang.

Dalam buku Tuhan Maha Asyik, dituliskan bahwa Tuhan berfirman kepada Nabi Daud As: "Engkau berkehendak, Aku berkehendak. Yang berlaku adalah yang Aku kehendaki. Jika enkau berserah diri kepada kehendak Ku, Aku memenuhi kehendakmu, dan jika tidak, enkau akan lelah mengejar kehendakmu 
sedangkan yang terjadi adalah kehendak Ku jua" Sebagai manusia kita hanya dapat memilih yang terbaik untuk kita, karena pilihan kita merupakan piliahan Tuhan pula. Manusia hanya menjalankan tugas dan fungsinya sebagai makhluk untuk menjalankan kehidupan dan Tuhanlah yang mengatur kehidupan ini.

Berbicara kehendak Tuhan ataupun kehendak manuisa, dalam pemahaman Ilmu Kalam atau Teologi Islam, ini bersangkutpaut dengan salah satu aliran kalam yang memahami bahwa kehendak manusia atau takdir manusia telah diatur tanpa ada daya manusia sebagai pelaku kehidupannya, paham ini disebut dengan paham Jabariah. Paham Jabariah berarti menghilangkan perbuatan manusia dalam arti sesungguhnya dan menyandarkannya kepada Allah SWT. Dengan kata lain manusia mengerjakan perbuatannya dalam keadaan terpaksa. ${ }^{10}$ Diantara dokrin Jabariah ada pendapat bahwa segala perbuatan manusia bukan merupakan perbuatan yang timbul dari kemauannya, melainkan perbuatan yang dipaksakan atas dirinya. Misalkan, kalau seseorang mencuri, perbuatan mencuri itu bukan terjadi atas kehendak sendiri, melainkan karena qadha dan qadarnya Tuhan yang menghendaki demikan. ${ }^{11}$ Ini lah paham Jabariah yang mempunyai paham bahawa qadha dan qodar Tuhan yang berlaku bagi segenap alam semesta ini, tidakalah memberi ruang atau peluang bagi adanya kebebasan manusia untuk berkehendak dan berbuat menurut kehendaknya.

Selain pahamam Jabaraiah adapun paham yang membahas mengenai kehendak Tuhan dan manusia adalah paham Qodariah. Berbeda dengan Jabairah, paham Qodariah mempunyai pandangan bahwa manuisa mempunyai kehendak sepenuhnya menguasai dan menentukan apa yang terjadi pada kita, bukan Tuhan. Qodariah adalah aliran yang percaya bahwa segala tindakan manusia tidak diintervensi oleh tangan Tuhan. Aliran ini berpendapat bahwa tiap-tiap manusia adalah pencipta bagi segala perbuatanya, ia dapat berbuat sesuatu atau meninggalkannya atas kehendaknya sendiri. ${ }^{12}$ Dengan demikian manusia itu bebas menentukan dirinya sendiri, memilih beramal baik atau buruk, karena mereka harus memikul resiko dosa kalau berbuat munkar dan berpahala jika berbuat baik dan taat.

Setelah manusia mengerti bahwa ia sebenarnya adalah wayang atau lakon. Paling ditakutkan ketika manusia lupa pada esensi awal penciptaan.

\footnotetext{
${ }^{9}$ Sujiwo Tejo dan Dr. MN. Kamba, Tuhan Maha Asyik, 19.

${ }^{10}$ Abdul Rozak dan Rosihon Anwar, Ilmu Kalam, 82.

${ }^{11}$ Abdul Rozak dan Rosihon Anwar, Ilmu Kalam, 85.

${ }^{12}$ Abdul Rozak dan Rosihon Anwar, Ilmu Kalam, 87.
} 
Manusia menjadi larut dalam lakon sehingga tidak mau mencari zat dari lakon tersebut.

Marhaen yang oleh masyarakat umum dikenal sebagai cerita dimana marhaen sebagai petani yang memilik lahan dan alat alat pertanian sendri, kala itu pernah di kunjungi secara langsung oleh presiden RI pertama dan marhaen dijadikan sebagai sebuah contoh rakyat mandiri yang perlu ditiru. Namun disislain prespektif yang berbeda diuturakan oleh Buchori yang terpikir oleh perkataan guru biologinya yang pernah menjelaskan bahwa nama marhaen adalah sebuah singkatan dari pemikir-pemikir hebat yaitu marx, hegel dan engel. Karena waktu itu soekarno sangat mengagumi pemikiran-pemikiran dari para tokoh tersebut, sehingga setiap menemukan seseorang degan ide dan gagasan yang luar biasa, dinamai oleh bungkarno marhaen untuk laki laki dan marhaeini untuk perempuan. Pangestu berpendapat agar apa yang disampaikan oleh Buchori tidak disebarluaskan kepada masayarakat. Hal ini dikarenakan jika masyarakat mengetahui cerita sesungguhnya dari sejarah marhaen itu sangat sigkat yang berbeda dengan pandangan masyarakat umumnya, maka tidak akan ada cerita yang menarik tentang marhaen.

Tuhan mampu untuk menciptkan semuanya yang ada, dan berproses sesuai dengan apa yang sekarang kita alami, namun tuhan pun mampu jika Ia ingin mengubah proses nya atau jalan ceritanya menjadi yang berbeda dari apa yang telah terjadi samapai detik ini. Dalam cerita marhaen ini berbicara tentang proses sejarah seabagai urutan kejadian atau peristiwa, dimana proses terjadinya peristiwa dari masa kemasa yang didalamnya terdapat dramatisasi peristiwa, yang bertujuan agar peristiwa itu lebih menarik. Dramtisasi dalam sekenario yang telah Tuhan lukiskana atau dalam sejarah yang telah berlangsung, ini dapat mempengaruhi kesadaran, harapan, dan semangat baru pada kehidupan di masa yang akan datang.

Kebiasaan akan mendidik karakter pada diri manusia untuk membentuk jati diri pada dirinya, kejadian yang berulang ulang yang dilakukan secara konsisten yang dilalui oleh manusia itu akan menjadi sebuah kebiasaan dan nantinya akan menjadikan kebiasaan itu menjadi dirinya. Namun karakter ini suatu waktu bisa mengalami perubahan tergantung individunya, segala sesuatu yang ada dapat mengalami perubahan, kecuali Tuhan yang kekal dan abadi. Perubahan pada diri seseorang dapat dipengaruhi oleh pengalaman dan pendidikan atau perasangka dan perkiraan.

Seperti dalam buku Tuhan Maha Asyik, dianalogikan bahwa buchoir dan kapitayan mereka sangat takut ketika melihat cacing, namun sebelumnya 
kapitayan tidak pernah takut dengan cacing, seiring berjalan nya waktu dan ada beberapa faktor faktor yang mempengaruh mereka untuk membenci cacing, salah satunya yaitu ketika mereka tidak nyaman ketika mencium bau tanah yang didiami cacing ataupun merasa jijik memegang lendir yang ada pada tubuh cacing. Jadi prasangka atau mindset mereka yang menjadikan mereka takut terhadap cacing.

Dalam beragama mindset atau perasangka dapat mempengaruhi kondisi prilaku manusia dalam keberagamaan. Kitab suci yang berasal dari Tuhan yang sifatnya kekal, dapat diartikan atau ditafsirkan berbeda beda oleh manusia, tergantung kondisi lingkungan dan konsidi sosialnya. Kondisi ini dapat dihasilkan melalui tiap tiap individu yang mempunyai pengalamanpengala man yang berbeda beda. Prilaku manusia merupakan sebuah ciri kebudayan, yang nantinya akan menjadikan perbedaaan dalam menafsirkan agamanya. Agama akan meberikan dasar teologi bagi perilaku kebudayaan sedangkan kebudayaan akan menjadikan energy baru pada agama, dan perosesl akulturasi dalam beragama yang menyebabkan agama dapat bertahan dan membangun peradaban manusia.

Tuhan menciptkan manusia dengan wujud yang sempurna, dan meraka diberikan kemampuan dalam berpikir, ini lah yang membedakan manusia dengan makhluk lainya. Manusia dapat memilih jalannya namun semua itu tentu sudah ditetapkan oleh Tuhan. Manusia mempunyai cara pandang atau cara berpikir yang berbeda-beda dengan manusia lainya. Seperti dalam analogi yang diperankan oleh Cristine, Pangestu, Buchori, Samin dan teman-teman yang lainya ${ }^{13}$. Mereka mencoba mempresepsikan tingkah laku yang sedang diperankan oleh Samin. Semuanya mempunyai pandangan yang berbeda-beda tentang prilaku yang sedang diperankan oleh Samin, karena semuanya mempunyai cara berpikir yang tidak sama dengan yang lainnya dan mempunyai sudut kebenaran yang berbeda.

Berbeda pandangan atau berbeda presepsi itu adalah hal yang wajar, pasalnya kebenaran pada diri manusia itu sifatnya relatif dan yang mutlak itu hanyalah Zat yang Maha Esa, Maha absolut. Ini lah yang Sujiwo Tejo dan Nursamad Kamba coba jelaskan kepada para pembaca dalam judul Zat. Dimana berbeda pandangan pemikiran terhadap sesuatu itu adalah hal yang biasa, yang terpenting adalah bagaimana cara kita dalam mengambil setiap hikmah yang terjadi dari setiap pristiwa atau fenomena yang ada.

Judul cerita "Diri" menceritakan tentang orang gila yang berbicara sendiri. Dalam cerita ini, orang yang berbicara sendiri ini bukan orang yang

\footnotetext{
${ }^{13}$ Sujiwo Tejo dan Dr. MN. Kamba, Tuhan Maha Asyik, 46
} 
berbicara terus menerus seperti $\mathrm{Ny}$ Christine yang selalu mengomeli siapa saja. Orang gila dianggap berbicara sendiri didalam keheningan, namun orang gila tersebut berbicara tidak melalui mulutnya. Hal ini dianalogikan dalam buku Tuhan Maha Asyik, dimana dalam hening manusia menyatu dengan jati diri yang sesungguhnya. Jati diri disini adalah cermin cahaya Tuhan. ${ }^{14}$

Tuhan berwujud pada diri manusia sebagai cermin kebaikan, ketika manusia memandang cermin, maka bukan kaca dilihat melainkan dirinya sendiri. Ketika manusia bertbuat baik pada orang lain, maka sesungguhnya ia telah berbuat baik pada dirinya sendiri. Ini sama dengan ketika manusia menyakiti orang lain, dengan secara tidak langsung dia itu menyakiti dirinya sendiri. Maka wajar saja jika manusia yang menyakiti diri sendiri dianggap tidak waras. Tapi lebih gila lagi jika agama dan atas nama Tuhan menjadi alasan untuk membenci dan menyakitu satu sama lain. ${ }^{15}$

Judul "Mengingat" menjadi cerita penutup pada buku Tuhan Maha Asyik. Dijalaskan dalam judul ini, manusia harus senantiasa mengingat Tuhan supaya tidak terjerumus dalam cara pandang yang terbentuk dari luar dirinya ataupun egonya. Karena Tuhan telah merancang diri manusia seperti komputer, yang telah dipasang software sejak awal Tuhan menciptakan manusia. Sehingga manusia dapat mengsave apa saja yang masuk kedalam dirinya. Dalam judul ini juga dijelaskan bahwa dalam mengingat Tuhan artinya sama dengan kembali pada kesejatian dirinya, dimana Tuhan akan terasa dekat dengan diri sendiri.

Maka semakin dekat manusia dengan Tuhan akan semakin bertambah termanifestasi pula sifat-sifat kebaikan dan kesempurnaan-Nya pada dirinya. Ini merupakan salah satu tuagas agama yang esensial, dimana agama dapat membimbing umat manusia kembali pada kesejatian diri manusia. $^{16}$

\section{Makna Teologi yang Terkandung dalam Novel Tuhan Maha Asyik}

Buku Tuhan Maha Asyik adalah buku yang membahas mengenai Tuhan, namun buku ini dirancang secara sengaja agar berbeda dari menstream. Jika pada buku yang membahas Tuhan pada umumnya adalah membahas mengenai konsep-konsep keTuhanan, justru buku ini menyuguhkan cara berpikir memahami mengenal Tuhan melalui jati diri yang sesungguhnya,

\footnotetext{
${ }^{14}$ Sujiwo Tejo dan Dr. MN. Kamba, Tuhan Maha Asyik, 111

${ }^{15}$ Sujiwo Tejo dan Dr. MN. Kamba, Tuhan Maha Asyik, 114.

${ }^{16}$ Sujiwo Tejo dan Dr. MN. Kamba, Tuhan Maha Asyik, 230.
} 
bukan diri yang dibuat oleh masyarakat ataupun ego pribadi, maka dari itu buku ini menjadikan orang-orang untuk asik dalam mengenal Tuhan, baik itu dalam bentuk kerinduan kepada-Nya, ataupun cara hidup yang rukun tanpa harus berselisih paham mengenai kepercayaan terhadap Tuhan. Dalam setiap pembahasannya buku Tuhan Maha Asyik ini memiliki makna teologis yang menarik untuk dikupas. Untuk mengupas makna yang ada dalam buku Tuhan Maha Asyik ini, penulis menggunakan Hermeneutik sebagai pisau analisnya.

Hermeneutik sebagai ilmu untuk memahami teks, dapat digunakan sebagai metode yang menjadikan makna dari sebuah teks menjadi dapat dipahami atau dapat menjelaskan sesuatu yang tersirat menjadi tersurat. Untuk mengupas makna teologi yang ada pada buku ini, penulis mencoba menggunakan metode hermeneutik Schleiermarcher yaitu interpretasi psikologis, dimana interprestasi ini dibagi menjadi dua tahapan. Yang pertama adalah tahapan divinatory dan yang kedua adalah comparative. Tahapan Divinatory merupakan tahapan dimana penafsir mencoba untuk menjadi penulis dan mencoba untuk berpikir dan menemukan dirinya seolah dia adalah penulis itu sendiri. Tahap comparative adalah tahap membandingkan peulis dengan penulis lainya yang bergerak atau berkarya dalam bidang yang sama. ${ }^{17}$

Buku Tuhan Maha Asyik mempunyai beberapa judul cerita, salah satunya dalam bab Wayang manusia itu di ibarat kan sebagai wayang, dan Tuhan berperan sebagai dalangnya, dimana sang dalang mempunyai kekuasaan dalam mengatur dan memerintahkan jalannya cerita. Manusia mengikuti apa yang dikehendaki oleh Tuhan, walaupun seperti itu namun manusia diberi kesempatan untuk memilih jalan hidup yang akan diambil, tapi lagi lagi kehendak Tuhan lah yang menentukannya. Seperti dalam kutipan buku Tuhan Maha Asyik sebagai berikut :

"Namanya juga Tuhan maka kekuasaanya pasti absolut. Tiada yang terjadi diluar kehendak-Nya. Sesuatu tidak terjadi jika Dia tidak menghendaki"18

Dalam paham jabariah, perbuatan manusia diciptakan Tuhan dalam diri manusia. Paham ini juga menganggap manusia tidak mempunyai kemampuan dan daya untuk mewujudkan perbuatannya. Menurut paham jabariah, manusia tak ubah sebagai wayang yang tidak bergerak dikala

17 Farhan, Hermeneutik Romantik Schleiermarcher Mengenai Laba Dalam Muqadimah Ibnu Khaldun, Surabaya; Universitas Airlangga, 2016; 64.

${ }^{18}$ Sujiwo Tejo dan Dr. MN. Kamba, Tuhan Maha Asyik, 119. 
digerakan oleh dalang. Sementara menurut faham Qadariyah, manusia mempunyai kebebasan dalam berkehendak dalam menentukan perbuatanperbuatannya dan perbuatan-perbuatan manusia tidak terikat pada kekuasaan dan kehendak mutlak Tuhan. ${ }^{19}$

Manusia merupakan mahluk yang dilengkapi oleh Allah dengan sarana berfikir, tapi sangat disayangkan kebenayakan dari manusia tidak menggunakan apa yang telah disarana kan kepadanya dengan sebagaimana mestinya, bahkan banyak manusia tidak pernah berpikir terlebih dahulu dalam bertindak. Maka dari itu yang paling penting untuk difikirkan secara mendalam oleh setiap indivdu manusia yaitu tujuan dari penciptaan dirinya, yang kemudian segala sesuatu yang ia lihat di alam sekitar dan kejadiankejadian yang ia jumpai selama hidupnya. Tuhan sebagai pencipta alam raya ini dengan semua fenomena yang ada didalamnya dan Dia Maha berkehendak atas segala sesuatunya. Jika Tuhan menghendaki segala sesuatu maka terjadilah, dan perlu kita ketahui bahwa Tuhan sebagai pencipta langit dan bumi, kita sebagai manusia senantiasa memahami segala kehedak atas apa-apa yang terjadi di alam raya ini.

Buku Tuhan Maha Asyik menyuguhkan dialog-dialog anak-anak dengan gaya khas celetukan dan guyonan ala bocah. Sujiwo Tejo dan Nursamad Kamba sengaja menhadirkan dialog anak-anak sebagai pembuka dalam setiap awal judul cerita, adapun maksud dari itu semua adalah karena pengearang ingin mencoba mengajak si pembaca untuk berpikir seperti anakanak. Dimana anak-anak itu selalu berpikir atau berprilaku dengan apa adanya tanpa dipaksakan atau tidak ada yang dibuat buat dalam prilaku atau cara berpikirnya. Dengan cara seperti ini manusia dapat mengenali Tuhan nya, maka dari itu manusia harus kembali kepada diri yang sesungguhnya atau diri yang fitrah.

Tuhan itu adalah sesuatu yang mendominasi diri manusia, untuk mencapai itu manusia harus masuk kedalam dirinya yang sedalam dalamnya. Karena Tuhan tidak bisa dicapai oleh akal, akal hanya bisa menangkap sesuatu yang bersifat materil, sedangkan Tuhan itu imateril yang hanya bisa dicapai melalui pendekatan spiritual. Untuk itu manusia dapat melakukan pendekatan spiritual dengan cara masuk kedalam diri yang terdalam, sehingga nantinya akan menemukan nurani dan akal sehatnya.

Untuk mencari makna teologi dalam buku Tuhan Maha Asyik, kita dapat memahaminya dalam judul Diri. Ada 4 bagian judul Diri yang terdapat pada buku Tuhan Maha Asyik, yaitu Diri (1), Diri (2), Diri(3) dan Diri(4).

\footnotetext{
${ }^{19}$ Harun Nasution, Teologi Islam, Aliran-aliran Sejarah Analisa Perbandingan, 118.
} 
Menurut Nursamad Kamba, manusia memiliki beberapa lapisan diri, yaitu diri sejatinya, diri ego, dan diri yang terbentuk oleh masyarakat atau lingkungan sekitarnya. Diri sejatinya adalah diri yang fitrah, diri yang diberikan oleh Tuhan pada saat awal penciptaan sebelum terdokrin oleh sesuatu diluar dirinya. Sedangkan diri ego adalah diri yang mementingkan kepenting pribadinya.

Pada judul cerita Diri ini, penulis melihat bagaimana cara pengarang menyampaikan makna keberTuahanan yang sesungguhnya. Karena Tuhan tidak dapat dilogika kan dan Tuhan adalah sesuatu yang imateril, maka Tuhan hanya dapat dipahami dengan nurani atau intuisi.

Dalam judul "Diri (2)", terdapat pembahasan mengenai kemanunggalan Tuhan. Dalam agama isalam kita meyakini bahwa Allah itu Ahad (Esa), tidak ada Tuhan selain Allah. Seperti pada kutipan dibawah ini, pengarang mencoba menjelaskan bahwa Tuhan itu adalah Esa.

"Dia satu, satu bukan karena ada bilangan lain, melainkan karena Dia memang satu-satunya, Tunggal." 20

Manusia sejatinya adalah makhluk yang mempunyai keyakinan kepada yang ghaib yang mempunyai kekuatan yang besar yang ada diluar pada dirinya. Dalam sebuah agama, Tuhan dianggap sebagai kekuatan besar yang dapat membantu umat manusia dalam menjalankan kehidupannya. Ajaran islam menganggap bahwa kenyataan tersebut sebagai fitrah. Fitrah dapat dikatakan sebagai sebuah keadaan kebertauhidan, yaitu sebuah keyakinan terhadap Tuhan yang tunggal.

"Hakikat tawhid ialah meng-ahad-kan Tuhan. Memahamhi hakikat ahadNya Tuhan sebagai yang Satu, Esa, Tunggal. Ahad bukan "1" numerik yang mengasumsikan ada setaraanya, melainkan Esa, Tunggal. Tiada sesuatupun selain-Nya." ${ }^{21}$

Dalam buku Tuhan Maha Asyik, terkandung konsep monotheisme, yang dimana monotheisme adalah kepercayaan terhadap satu Tuhan. Monotheisme merupakan dokrin keagamaan yang berkeyakinan bahwa hanya ada satu Tuhan. Dimana Ia merupakan tingkat terakhir keyakinan manusia terhadap yang Esa dalam beragama. ${ }^{22}$ Ajaran ketuhanan monoteistik

\footnotetext{
${ }^{20}$ Sujiwo Tejo dan Dr. MN. Kamba, Tuhan Maha Asyik, 119

${ }^{21}$ Sujiwo Tejo dan Dr. MN. Kamba, Tuhan Maha Asyik, 121.

${ }^{22}$ Hasbi Arijal, "Problem Konsep Monoteisme dalam Agama-Agama Semit", Kalimah, 13, No.1 (Maret 201) 5.
} 
yang diajarkan Islam bersifat total. Totalitas monoteisme islam terumuskan dalam untaian kata-kata laa ilaaha illallah, yang berarti "tidak ada Tuhan selain Allah." Dilihat dari formulasinya, konsep tauhid laa ilaaha illallah mengandung rahasia hakikat dan efek yang sangat sentral bagi para penganutnya. ${ }^{23}$

Setelah kita memahami kemanunggalan Tuhan, selanjutnya kita akan membahas mengenali Tuhan melalui diri, diri yang sejati.

"Memang dipastikan tanpa mengenali diri, mustahil mengenali Tuhan. Tuhan bermanifestasi dalam jiwa manusia sebagai cermin yang merefleksikan Tuhan dan makhluknya. Ketika seseorang memandang cermin, yang terlihat bukanlah cermin, melainkan sosok dirinya."24

Pada kutipan diatas, kita dapat memahami bahwa peroses mengenali Tuhan dapat dilakukan dengan cara masuk kedalam hati nurani atau diri yang murni. Dengan seperti tu kita dapat menangkap kebaikan kebaikan Tuhan (manifestasi) pada segenap entitas yang ada sehingga diri orang lain adalah dirimu juga (tercermin) dan diri kita adalah diri orang lain juga. Maka dalam buku Tuhan Maha Asyik ini Nursamd Kamba mengatakan,

"jika kita menyakiti orang lain itu berarti kita menyakiti diri kita sendiri, dan sebalaiknya, jika kita membahagiakan orang lain maka kita telah membahagiakan diri kita sendiri." 25

Orang -orang yang beriman mempercayai bahwa alam semesta dan isi nya ini adalah ciptaan Tuhan, mereka yang berakal sehat menolak bahwa alam ini tercipta dengan sendirinya. Mereka yang berkeyakinan seperti itu sudah jelas menjadikan agama sebagai ajaran atau tuntunan penting dalam kehidupan didunia. Hampir sebagian besar manusia mempunyai keyakinan bahwa adanya kekuatan yang Maha Besar, Maha Cerdas yang menciptakan dan mengatur alam semesta serta diri manusia itu sendiri. (memasukan teori penciptaan).

\footnotetext{
${ }^{23}$ Roni Ismail "Hakikat Monoteisme Islam (Kajian atas Konsep Tauhid "Laa Ilaaha Illallah)", Religi, 10, No.2 (Juli 2014) 3.

${ }^{24}$ Sujiwo Tejo dan Dr. MN. Kamba, Tuhan Maha Asyik, 113.

${ }^{25}$ Muhammad Nursamad Kamba (pengarang buku Tuhan Maha Asyik), wawancara oleh Rahmat Firdaus, Komplek Cipadung Permai, Bandung, tanggal 20 Juli 2018.
} 
Dewasa ini manusia yang beragama terlampu banyak dibebani, seperti dibebani dari kewajiaban -kewajiban yang ada dalam agama, atau pemahaman dalam agama itu sendiri yang didominasi oleh hukum. Seperti kita ketahui bahwa tujan sebenarnya agama ada yaitu hanya semata-mata untuk mencapai ridho Tuhan, bukan dibebani ataupum terbebani, semuanya harus ikhlas, alhasil mereka beragama namun tidak berTuhan.

"Agama adalah hening, dalam hening manusia berbicara kepada diri sendiri, tapi ada kemungkinan yang terdengar oleh nya adalah firman-firman Tuhan. Dalam hening manusia menyatu dengan jati dirinya yang sesungguhnya; tiada lain adalah cermin cahaya Tuhan."26

Dalam beragama tujuan utama manusia adalah Tuhan, sedangkan untuk mencapai Tuhan menurut Nursamad Kamba manusia harus didalam keheningan pasalnya, Tuhan tidak bisa dibersamai dalam keramaian. Nursamad Kamba juga menambahkan bahwa keheningan yang dimaksud adalah keheingan jiwa bukan keheningan fisik. "Maksudnya agama adalah hening ialah bahwa agama bertujuan semata-mata hanya kepada Tuhan, sedangkan Tuhan tidak dibersamai kecuali dalam keheningan, yakni keheningan jiwa bukan kehening fisik. Maka ada ungkapan "Hening dalam keramaian", yakni secara fisik bisa ramai tapi jiwa dalam keheningan" tutur Nursamad Kamda. ${ }^{27}$

Agama sangat baik dan berguna serta mempunyai fungsi yang penting bagi kehidupan umat manusia, yaitu agama merupakan unsur mutlak yang dapat membina karakter pribadi dalam membangun kehidupan sosial yang rukun dan damai, agama juga dapat mendidik manusia agar memiliki jiwa yang tenang dan membebaskan belenggu perbudakan, berani menegakan kebenaran, memiliki moral yang terpuji dan agama dapat mengangkat drajat manusia lebih tinggi dari makhluk Tuhan yang lain. Namun untuk mencapai itu semua, manusia harus dapat mengenali Tuhan nya dan menjadikan Tuhan sebagai satu-satunya tujuan, dengan seperti itu Tuhan dapat membimbing manusia dan menyelamatkan manusia dari kehidupan dunia.

Untuk mengenali Tuhan manusia terlebih dahulu perlu mengenali dirinya sendiri., jati diri yang sesungguhnya, bukan diri yang dihasilkan dari lingkungan sosialnya atau diri pribadinya yang lebih mementingkan ego.

\footnotetext{
${ }^{26}$ Sujiwo Tejo dan Dr. MN. Kamba, Tuhan Maha Asyik, 111.

${ }^{27}$ Muhammad Nursamad Kamba (pengarang buku Tuhan Maha Asyik), wawancara oleh Rahmat Firdaus, Komplek Cipadung Permai, Bandung, tanggal 20 Juli 2018.
} 
Pada kutipan dibawah ini, Sujiwo Tejo dan Nursamad Kamba mencoba menjelaskan bagaimana manusia bisa mengenali Tuhan nya.

"Saat dirimu (kepentingan pribadi) tiada, maka Tuhan ada, dan saat Tuhan ada, maka dirimu yang sejatinya ada". ${ }^{28}$

Yang dimaksud diri yang tidak ada disini adalah diri yang ego atau diri yang lebih mementingkan kepentingan pribadi. Jika diri yang seperti itu akan sulit untuk menghadirkan Tuhan pada diri kita. Namun sebaliknya jika kita mentiadakan diri ego kita, maka diri kita yang sejati akan ada, nah diri sejati ini lah yang bersamaan dapat mengenali Tuhan pada diri kita. Begitu pun menurut Nursamad Kamba "dirimu yang paling dalam bukan diri mu yang dibentuk oleh ego, diri yang dibentuk oleh masyarakat, diri yang dibentuk oleh media sosial kita ataupun diri yang dibentuk oleh rasionaltas kita, tapi ada diri kita yang sejatinya, diri yang sejatinya itulah yang menangkap Tuhan". ${ }^{29}$

Setelah pengarang membawa kita bagaimana cara untuk mengenal Tuhan, melalui apa kita dapat mengenalnya, maka stelah itu pengarang mencoba untuk menjelaskan apa saja yang kita peroleh setalah mengenalNya. Dalam buku Tuhan Maha Asyik ini saya mengutip pada judul "Diri (2)" yang berbunyi sebagai berikut:

"Mengenali Tuhan Berarti menyatu dengan-Nya, menyatu dengan Tuhan berarti merefleksikan kebaikan-kebaikan dalam ke hidupan". ${ }^{30}$

Kalo kita membahas mengenai Tuhan maka segalanya yang ada pada Tuhan adalah hal yang positif, namun tidak menampikan juga bahwa Tuhan menciptakan hal yang negatif dan mempunyai sifat negatif pula karena Tuhan maha segalanya. Berbicara mengenai kebaikan yang Tuhan refleksikan dalam kehidupan, maka sesungguhnya Tuhan itu Maha pemeberi kebaikan. Kebaikan yang Tuhan berikan kepada makhluknya tak terbatas dan tanpa pamrih. Kebaikan Tuhan melimpah luas tak terbatas, begitupun dengan kasih sayang Tuhan kepada makhlunya.

"Diri-diri yang menyatu tidak mesti seragam. Subt ansi boleh satu, tapi peran harus beragam." (hal, 126)

\footnotetext{
${ }^{28}$ Sujiwo Tejo dan Dr. MN. Kamba, Tuhan Maha Asyik, 120.

${ }^{29}$ Muhammad Nursamad Kamba (pengarang buku Tuhan Maha Asyik), wawancara oleh Rahmat Firdaus, Komplek Cipadung Permai, Bandung, tanggal 20 Juli 2018.

${ }^{30}$ Sujiwo Tejo dan Dr. MN. Kamba, Tuhan Maha Asyik, 119.
} 
"Ibarat cahaya yang memancar dari sinar matahari, tidaklah dalam intensitas yang sama. Ada yang terang sekali, ada yang sedang dan ada pula yang sangat lemah." (hal, 128)

\section{Pemahaman DR. MN. Kamba tentang Tuhan dalam Novel Tuhan Maha Asyik}

Dalam buku Tuhan Maha Asyik, pembahasan mengenai Tuhan menjadi topik utama namun bukan membicarakan mengenai konsep-konsep tentang ke-Tuhanan melainkan pemahaman mengenai Tuhan. Untuk mengetahui pemahaman buku ini berbicara mengenati Tuhan, sejatinya kita harus masuk jauh ke dalam diri kita yang sesungguhnya. Pada buku Tuhan Maha Asyik terdapat judul "Diri", dimana dalam judul itu kita dapat memahami kesejatian diri. Setalah penulis mengupas makna Teologi yang ada pada buku Tuhan Maha Asyik, selanjut penulis akan membahas mengenai pemahaman Tuhan menurut pengarang buku Tuhan Maha Asyik yaitu DR. MN. Kamba. Tuhan merupakan suatu kekuatan yang dapat mengatur dan mengendalikan seluruh makhluk yang ada pada semesta ini, serta merupakan hakikat yang tertinggi dari semua dimensi yang mengada dalam kesemestaan yang ada didalamnya.

Ketika sikap keberTuhanan pada manusia diaplikasikan dalam wujud penghambaan dan pengabdian yang terlegitimasi dalam formalitas agama, maka agama dipandang sebagai sesuatu yang memiliki kebenaran mutlak dan universal. Secara filosofis Tuhan dan agama adalah dua hal yang tidak dapat dipisahkan, karena Tuhan yang terlepas dari agama maka Tuhan menjadi tidak mutlak dan pasti, dan sebaliknya agama tanpa Tuhan menjadi tidak memiliki arah yang jelas. Dewasa ini manusia banyak sekali yang Bergama tapi tidak berTuhan, yaitu mereka yang menghafal konsep-konsep yang ada pada agama namun tidak menyertai nilai-nilai keberTuhanan pada dirinya.

Sesungguh nya Tuhan itu tidak dapat dibicarakan dalam bentuk perdebatan, yang dimana pada zaman ini manusia bersikap egois saling mempertahankan pendapat mereka mengenai kosep keTuhanan menurut kepercayaan yang mereka pahami, Tuhan itu harus dihadirkan dan mengadirkan Tuhan itu tidak melalui perdebatan. Menurut Nursamad Kamba, manusia yang seperti itu merupakan manusia yang beragama namun tidak berTuhan. "Tuhan tidak bisa dibicarakan dalam bentuk perdebatan, tapi Dia harus hadir, Tuhan itu harus dihadirkan". Menurut Nursamad Kamba, "Banyak orang yang beragama tapi tidak ber-Tuhan, mereka rajin ke masjid, berpuasa, berzakat, tepi berTuhan nya kemana? Tuhan tidak dia kenal, dia cuman 
membayang-bayangkan, nah mereka itu paling tidak hanya menghafal konsep yang diajarkan ahli agam". ${ }^{31}$ Tambah Pak Nursamad Kamba.

Dalam proses menghadirkan Tuhan, manusia harus dapat mengahdirkanya melalui dirinya senidiri, karena Tuhan hadir dalam tiap-tiap diri manusia. Seperti kita ketahui pada buku Tuhan Maha Asyik, terdapat judul-judul mengenai "Diri". Ini adalah salah satu cara pengarang untuk dapat mengenalkan Tuhan kepada pembaca.

"Mengenali Tuhan Berarti menyatu dengan-Nya, menyatu dengan Tuhan berarti merefleksikan kebaikan-kebaikan dalam ke hidupan".

Pada kutipan diatas, adalah kutipan yang pe nulis ambil dari buku Tuhan Maha Asyik. Dalam buku Tuhan Maha Asyik proses mengenali Tuhan bisa melalui kebersatuan dengan Tuhan, adapun kebersatuan Tuhan ialah dengan merefleksikan kebaikan-kebaikan yang dilakukan dalam kehidupan. Semua pemeluk agama sepakat bahwa manusia harus melakukan kebaikan-kebaikan dimana Tuhan sendiri selalu memerintahkan dan mengajarkan segala sesuatu yang baik. Dalam Islam ada perintah untuk setiap pemeluk nya melakukan zakat dan sedekah, bagi mereka yang memiliki kelebihan harta. Bukan tanpa alasan Allah memerintahkan hambanya untuk melakukan itu, karena jika membayar zakat dan bersedekah Allah berjanji akan melipat gandakan hartanya hingga sepuluh kali lipat. Selain itu juga, zakat dan sedekah diyakini dapat membersihkan harta, karena kita sebagai manusia tidak tahu apakah harta yang ada pada kita itu halal ataukah haram. Dalam berzakat dan bersedekah, manusia dapat berbagi dengan mereka yang membutuhkan, pada tindakan ini manusia dapat saling tolong menolong dan ini adalah salah satu tindakan kebaikan yang selalu Allah tunjukan pada diri manusia.

Maka dari itu kebaikan-kebaikan Tuhan mendominasi pada diri manusia diri yang sesungguhnya, bukan diri yang terbentuk karena ego ataupun diri yang terbentuk melalui dokrin-dokrin yang ada diluar dirinya. Oleh karena itu, kita dapat menangkap kebikan-kebaikan Tuhan dengan cara harus masuk lebih dalam kedalam diri kita sendiri. Karena untuk mengenali Tuhan tidak cukup hanya dengan akal, tapi harus dengan intuisi. Tuhan

\footnotetext{
${ }^{31}$ Muhammad Nursamad Kamba (pengarang buku Tuhan Maha Asyik), wawancara oleh Rahmat Firdaus, Komplek Cipadung Permai, Bandung, tanggal 20 Juli 2018.

${ }^{32}$ Sujiwo Tejo dan Dr. MN. Kamba, Tuhan Maha Asyik, 119.
} 
bersifat imateril sedangkan akal hanya bisa menangkap sesuatu yang materil saja.

"Tuhan hanya bisa ditangkap dengan spiritual, Tuhan itu imateril, berarti harus dengan pendekatan spiritual. Nah cara pendekatan spiritual yang benar itu adalah, orang masuk kedalam diri, dalam diri yang terdalam orang akan menemukan nurani dan akal sehatnya", ${ }^{33}$ ungkap Nursamad Kamba.

\section{Simpulan}

1. Makna teologis yang terkandung dalam buku Tuhan Maha Asyik karangan Sujiwo Tejo dan DR.MN.Kamba, membahas mengenai kedudukan Tuhan dan manusia, dan cara manusia mengenali Tuhanya. Dimana Tuhan tidak hanya dikukung dan tidak hanya dijadikan penamaan-penamaan dalam sebuah pemaknaan, karena Tuhan tidak terdefinisikan. Tuhan itu dapat kita pahami melalui diri manusia, diri yang sesungguhnya, bukan diri yang terbentuk oleh ego ataupun oleh konsep-konsep dari lingkungan sekitar. Kedudukan manusia dengan Tuhan, dalam buku Tuhan Maha Asyik dijelaskan bahwa manusia itu di ibaratkan wayang yang berada dibawah kendali Tuhan seperti dalang. Tuhan berkuasa dalam mengatur nasib yang akan dilakoni sang wayang yaitu manusia. Namun manusia dapat memilih atau menjalankan sekenario Tuhan dengan apa yang mereka ingin kan tapi masih dalam jalur yang telah Tuhan tentukan. Seperti pada bab wayang, (sekilas tentang cerita wayang). Adapun dalam mengenali Tuhannya, manusia biasa melalui masuk kedalam jati diri yang sesungguhnya, dimana diri yang dimaksud adalah diri yang dalam keadaan fitrah, diri yang pertama kali diciptakan, bukan diri yang telah terdokrin oleh ajaran-ajaran yang ada diluar diri manusia. Tuhan hadir pada tiap-tiap diri manusia sebagai cermin, jadi ketika manusia memandang cermin, sesungguhnya bukan kaca yang mereka lihat melainkan dirinya.

2. DR. MN. Kamba, sebagai penulis buku Tuhan Maha Asik dan yang berlatar belakang sebagai dosen pengampu Tasawuf di perguruan tinggi negeri, mempunyai pemahaman tersendiri mengenai Tuhan, yaitu menurutnya, "Tuhan itu sesuatu yang mendominasi diri, untuk menangkap itu orang harus masuk kedalam dirinya sedalam dalam nya baru

${ }^{33}$ Muhammad Nursamad Kamba (pengarang buku Tuhan Maha Asyik), wawancara oleh Rahmat Firdaus, Komplek Cipadung Permai, Bandung, tanggal 20 Juli 2018. 
tertangkap. Kalo cuman akal tidak bisa, akal itu cuman nangkap sesuatu yang bersifat materil. Tuhan hanya bisa ditangkap spiritual, Tuhan imateril berarti harus dengan pendekatan spiritual". Dalam bukanya juga Nursamad Kamba, menjelaskan mengenai cara pendekatan spiritual, "cara pendekatan spiritual yang benar itu adalah, orang masuk kedalam diri, dalam diri yang terdalam orang akan menemukan nurani dan akal sehatnya. Dirimu yang paling dalam bukan diri mu yang dibentuk oleh ego, diri yang dibentuk oleh masyarakat kita, ada diri yang dibentuk oleh media sosial kita, ada diri yang dibentuk oleh rasionalitas kita, tapi ada diri kita yang sejatinya, diri yang sejatinya itulah yang menangkap tuhan". Maka tuhan maha asyik itu jika kita membicara tentang teologi yang menarik dan kita masuk kedalam wilayah kesejatian diri untuk mengenali Tuhan, itulah teologi dalam buku Tuhan Maha Asyik. Tuhan tidak dapat dikonsepsikan, ketika Tuhan dikonsepsikan maka Tuhan tunduk kepada rekayasa akal. Tuhan tidak bisa ditundukan oleh apapun karena Tuhan Maha Absolut, kemutlakan Nya itu mutlak absolut dari kemutlakan apapun.[] 


\section{DAFTAR PUSTAKA}

\section{Buku}

Abdul Rozak dan Rosihon Anwar, 2013, Ilmu Kalam, Pustaka Setia: Bandung.

Farhan, 2016, Hermeneutik Romantik Schleiermarcher Mengenai Laba Dalam Muqadimah Ibnu Khaldun,Universitas Airlangga: Surabaya.

Fazlur Rahman, 1985, Islam dan Modernitas, terj. Ahsin Muhammad, Pustaka: Bandung.

Harun Nasution, 2002, Teologi Islam; Aliran-aliran Sejarah Analisis Perbandingan, UI-Press: Jakarta.

Hasan Hanafi, 1994, Dialog Agama dan Revolusi, Pustaka Firdaus: Jakarta.

Hasbi Arijal, 2014, Problem Konsep Monoteisme dalam Agama-Agama Semit, Kalimah, 13, No.1 Maret.

Hussein Bahreis, 1981, Ajaran-ajaran Akhlak Al-Ghazali, Al-Ikhlas: Surabaya.

Komaruddin Hidayat, 1996, Memahami Bahasa Agama Sebuah Kajian Hermeneutik, Paramadina: Jakarta.

Kurt F. Leidecker, 1976, "Hermeneutics" dalam Dagobert Russel (ed), dictionary of philosophy, Adams dan co: New York.

Muhammad Al-Fayyadl, 2012, Teologi Negatif Ibn Arabi: Kritik Metafisika Ketuhanan, LKiS: Yogyakarta.

Roni Ismail, 2014, Hakikat Monoteisme Islam (Kajian atas Konsep Tauhid "Laa Ilaaha Illallah), Religi, 10, No.2 Juli.

Sujiwo Tejo dan DR.MN. Kamba, 2017, Tuhan Maha Asyik, Imania: Tanggerang.

\section{Wawancara}

Muhammad Nursamad Kamba (pengarang buku Tuhan Maha Asyik), wawancara oleh Rahmat Firdaus, Komplek Cipadung Permai, Bandung, tanggal 20 Juli 2018. 